\title{
GENDER IMBALANCE IN THE LAW
}

\author{
Interview of Christine Grice ${ }^{*}$
}

Following the release of the Auckland Women Lawyers' Association funded research Women's career progression in Auckland law firms: Views from the top, views from below, ${ }^{1}$ the Executive Director and past-President of the New Zealand Law Society, Christine Grice, did some research into the situation of women QCs. She explored the issues facing senior women lawyers in an interview with Kathryn Ryan on "Nine to Noon" on 10 March 2014. On 6 June 2014, the 14 new QCs announced, included four women, with the Attorney-General saying: "I am aware there are very talented women in the profession who remain reticent about putting their names forward and I hope to see increasing numbers represented in the future."

Kathryn Ryan (KR): The latest round of Queen's Counsel appointments, QC appointments, has again highlighted the gender imbalance at the top end of the legal profession. While women make up 46 per cent of the profession overall, only 15 per cent of Queen's Counsel are women and only 22 per cent are partners in law firms. Only 16 women applied to be QCs last year, none were from Wellington, which has the highest number of lawyers per capita in the country. Four women were appointed out of a 116 in total, and the Law Society has been endeavouring to find out why, and what it can do to improve the numbers. With me in the studio is the Executive Director of the Law Society, Christine Grice.

That figure on the face of it, is astonishing.

Christine Grice (CG): Yes, well it is interesting, given that women have been admitted to the legal profession in great numbers since the 1980s, and certainly since the 1990s they actually account for more than 50 per cent of admissions. The latest statistics we've got is that women make up 62 per cent of the admissions and, as you say, 46 per cent in practice.

* Interview with Christine Grice, Executive Director of the New Zealand Law Society (Kathryn Ryan, Nine to Noon, Radio New Zealand National, 10 March 2014). This is an edited transcript of the interview. Audio of this interview can be heard at Radio New Zealand "Gender Imbalance in the Law" (10 March 2014) <http://www.radionz.co.nz/audio/player/2588397>

1 Judith Pringle and others Women's career progression in Auckland law firms: Views from the top, views from below (Auckland Women Lawyers' Association, 2014). 
KR: So 116 QCs. What about application levels? Were the applications higher than that or does a lesser number apply in the first place?

CG: We know that about 16 women applied for QC appointment in this round, which is not a great number, but at the same time the pool of barristers who can apply, who fit the criteria, is quite limited. So there is also an issue about the nature of the role.

KR: So, what are the requirements and what is the process for the appointment of Queen's Counsel?

CG: The appointment is made by the Attorney-General and in consultation with the Law Society and the Bar Association and, of course, the Chief Justice. There is an application process which includes quite a rigorous form to fill out. I know that a number of QCs who are now appointed have said that they have applied numerous times, five or six times, and report that it is quite a "bruising" process. This does not relate just to women. There are a lot of very talented, brilliant male barristers who have applied a number of times before they have got it.

KR: And it needs to be, given the status of the position.

CG: It is the leadership of the profession, the face of the profession, and where a substantial number of appellate judges were appointed from, particularly the Supreme Court and the Court of Appeal. When you look at the statistics, that is quite interesting, because there have been a number of appointments from firms of lawyers to the Bench. That is the general case in New Zealand and has always been the case. But the appointments in the appellate courts: the Supreme Court and Court of Appeal are still mainly QCs.

KR: When you talked about the criteria, what level of the law, what level of experience do you have to have had before you even consider going through the process?

CG: You have to have had substantial experience. I think most of applicants would have had at least 20 to 30 years' experience. The overarching requirement is leadership in the profession. There is a lot of material they have to give about the cases they've done, about how they've been reported and why they're important. So there are a number of factors but the overall criteria is:

(a) You are a barrister. There are about 230 women likely to be eligible in that category; and,

(b) That you are excellent, that you've done the litigation, you've done the advocacy and you've proved yourself a true leader of the profession.

KR: I wonder if we are playing catch up in some ways. If you need 20 to 30 years' experience we are talking now about 46 per cent of the profession being women, I think it's probably a majority of students these days.

CG: Forty-six per cent are women who take practising certificates but 62 per cent of those who are coming into the profession are women. 
KR: Right. Is the possibility though that 20 or 30 years ago that gender balance wasn't as even or indeed hadn't tipped to be majority women and that therefore those with 20 to 30 years' experience are lower in numbers than those who've got five to 10 or 15 years' experience?

CG: 1993 was the first year that women exceeded 50 per cent of the intake of admitted lawyers.

KR: And that's more than 20 years ago.

CG: It's more than 20 years. And it was moving toward that for quite a number of years prior to 1993.

KR: Are we seeing similar discrepancies in the number or the gender balance among judges or is that a little less pronounced?

CG: It's less pronounced and I think that in judges we have got approximately 29 per cent who are women across the board. There's been quite a move to making sure that there have been women appointed to the bench.

KR: But it's a smaller number obviously as well isn't it?

CG: It's a smaller number who are eligible. Yes, that's right. And it's also a wider pool because women appointed to the bench, or indeed anyone appointed to the bench, needs to be a lawyer of course with substantial experience but that experience might have been in a firm, as a partner in a firm. There are a number of different pathways. There are also people who have had academic careers. That's a rarity but it's happened. There's a greater pool.

KR: When you look at the number of the QCs, and they were just announced a week or two ago weren't they? You have 16 women apply and four were appointed. That's a 25 per cent success rate. Is that pretty much in line with the success rate for the male applicants? Is the real problem the small number applying?

CG: Yes, I think that's a fair comment and application numbers is one of the immediate things we need to tackle. A lot of ink's been spilt over these issues, in not just law, it's across the professions and in boards in commercial organisations. The arguments have been made. There is a problem with applications as there's a very limited number of women who will be eligible according to that criteria. There is an argument that you don't want to dilute excellence, nonetheless there are many excellent women who have not applied.

KR: Are they telling you why?

CG: Some of them just feel that they are not up to it, that they are concerned about a responsibility that comes with it. When you're a QC you would usually lead a case. When you're a barrister you will junior for a more senior lawyer. The workload will be different. And I also anecdotally hear that women are not getting the same sort of work that men get in commercial law. I am a litigator of 30 years' experience, practised in a firm and specialised in commercial litigation, 
but one of the advantages I had was being from a provincial place, from Hamilton, so I had plenty of good commercial work. I think in the commercial areas there are multi-faceted issues about relationships and networks which we hear about in the literature.

\section{KR: Meaning?}

CG: Meaning if you've got commercial relationships that that might drive the work; the networking issue. Those types of things establish the pipelines for the work. There has just been some recent research that was commissioned by the Auckland Women Lawyers' Association (AWLA) which looked at women in large firms, and that seems to indicate that there are clients who say they would prefer to have a male rather than a female lawyer. But I think that will change because as we are seeing the change in balance on boards in the commercial area we will see clients becoming more demanding about, in fact having access to the full range of talents and diversity.

KR: So in the commercial area it's an allied problem. A very low number of women on boards, and the lack of diversity on boards generally might feed into, "Oh no, we just deal with what we know".

\section{CG: That's right.}

KR: Are you talking politely about the old boys' network or is it slightly more subtle than that?

CG: Well, I don't think it's as easy as just "the old boys' network". There are multiple factors. It's a structural societal issue, so there's no one answer. The AWLA research, which was done and supported by the New Zealand Large Firms Group, does indicate that there is alive and well an "old boys network". This was the perception in the quantitative research. The perception is that from the males interviewed, that that's not as strong as the females see it. There are quite interesting differences in perceptions by the males and the females at a number of levels about the firms and also the views of those lawyers pre- and post-partnership.

\section{KR: Such as?}

CG: For instance, research indicates that the perception about women leaving the law by the males is that they need to go off and have a family and that's why they do it. Most women think that that is not the case. It's the structural things. They would actually like to stay, they have a love of the law but actually staying means all sorts of added responsibilities including the need to actually have someone look after the children. It's a difficult to balance career with a family. So almost all of women who responded, some 95 per cent, endorsed the proposition that there was a trend for women to leave the firms or the profession. In contrast, 30 per cent of the men responded and disagreed with this proposition. So it's hard to know what this means until there's further research. This was a quantitative approach which presented the information rather than reaching conclusions. There are very different perceptions within the firms. 
KR: So sorry, just to be clear, are you saying the men were perceiving that the women were leaving because of family demands and the women were not, were saying that's not the case?

CG: Yes.

KR: So, are they leaving though and if so have they given you reasons why they leave?

CG: The statistics that we've got, certainly in early career, show that men and women leave at equal rates but by mid-career we see more women leaving as, of course, they have further responsibilities outside the home and what not. That results in those statistics show these days -61 , 62 per cent are being admitted to the profession while only 46 per cent are in practice and then you dig deeper and see 20 per cent are partners in firms, 30 per cent are judges. It's difficult to say what the drivers are. It's clear that what we've been doing for the last 20 years, such as the type of mentoring, saying that it will happen and that the trickledown effect means it's going to happen, hasn't worked.

KR: What I'm also hearing is a shift in weighting from this business of the family life pressures and perhaps taking a break and then coming back and finding it impossible to get back in. What I'm hearing from you almost is that the difficulty of advancement in getting the cases you need and possibly the frustration of that might be just as big a factor if not bigger.

CG: Yes, I think that is a big factor. The role of a lawyer is very stressful in that type of litigation. It takes a lot of emotional and psychological energy as well as the work and time involved.

KR: Is there anything you can do about that? I remember talking to a very, very senior partner in one of the biggest US law firms, and I mean biggest, like hundreds of lawyers, who was on a mission to begin to change the way lawyers live their lives with you know, much more flexibility and sort of family-friendly policies and all these kinds of things. When push comes to shove, particularly when it comes to criminal trials, is it always going to be an enormously demanding job and some people are going to say no, no more or this is as far as I want to go on it.

CG: There always will be some, but why the big distinction and why the difference? The Attorney-General has said he wants to know why, he wants to examine it. For QCs who are at the peak of the profession. We've got to start looking at the structural issues and how we can remedy them. It's across the profession.

KR: How would you do it if it's a question of it being so network-based and particularly you are mentioning in the commercial field, you can't start dictating to clients who it is they have as their lawyer can you? Or can you?

CG: You can give firms tools to make sure they showcase the women and their talents, and that the clients want them. Things are changing in the boardroom as well so there are a whole lot of things that are changing that now need some proactive steps at every level. 
KR: Were you startled by those figures four out of 116 in the latest round of Queen's Counsel appointments were women? Did that figure startle you even?

CG: When I saw that four out of 16 had applied (none from Wellington) I considered the figures were low. They followed the proportions generally. 15 per cent of QCs are women. That's a very low statistic for the leaders of the profession, 20 years after we have had 50 per cent plus of women coming into the profession.

KR: Very interesting work and it's ongoing by the sounds of it Christine.

CG: It is. 